members had either become literate or had lost interest. These were replaced by new groups in pockets not previously covered and by second stage groups (shule ya jux) providing further instruction and practice in reading, writing and arithmetic.

By the end of I95 I 3,500 literacy primers had been sold and 36r literacy certificates had been issued. During 1952 the campaign reached Middle Pare and the South Pare Mountains and by December $1952 \mathrm{Mr}$. Mason had records of some 120 literacy groups with about 2,000 attending; by the end of the year a total of 850 literacy certificates had been issued since the start of the campaign.

During 1953 the campaign took in the extreme south of the district which had not previously been covered. By this time, however, the tempo of the campaign had slowed down considerably due to a variety of factors-two of them being a poor agricultural season and a rather less enthusiastic response to the campaign on the part of the people of the more southerly areas who are considerably more backward than their fellow tribesmen of the north. During 1954 the campaign, in so far as official encouragement and support were concerned, was finally wound up, by which time 1,322 literacy certificates had been issued since the start of the campaign.

Mr. Mason wrote a detailed report in I95I on the methods used in the campaign up to that time. These methods changed but little right up to the end of the campaign except that, as the groups spread more widely over the district, supervision and control tended to become more and more tenuous. Thus in the later stages of the campaign almost all teaching was done by volunteer leaders while the trained staff toured the many and widely dispersed groups as much as they could. Visits from the Social Development Officer, District Commissioner, chiefs and other prominent persons were found to be one of the most important factors in maintaining the enthusiasm of the learners, but such visits became more difficult as the groups grew more numerous and widespread.

A monthly district newspaper in Swahili was founded by the Social Development Team in April I95I, to provide follow-up literature, to stimulate community development, and as a valuable project in itself. The first issues of Habari za Upare were cyclostyled and illustrated with photographs stuck in by hand. Circulation was only a few hundred copies. The paper has since grown to a 12-page ( $16 \times \mathrm{I} \mathrm{r}$ in.) paper, printed in the neighbouring town of Moshi, profusely illustrated and well on the way to earning enough revenue from advertising and sales to be self-supporting. Circulation is now in the neighbourhood of 3,000 copies per month. The paper has naturally always made a special feature of the mass literacy campaign and other community development activities. Habari za Upare has now been largely handed over by the Social Development Officer to the Pare Council, who employ their own full-time editor.

The supply of other types of follow-up literature has always presented something of a problem. The reading and writing of letters must provide by far the most important form of follow-up for new literates, and the ability to exchange letters was often given as their motive by adult learners. Apart from letters and Habari za Upare, the other vernacular newspapers form an important source of follow-up literature; these are the Tanganyika Government's popular Mambo Leo (monthly) and the weekly Habari za Leo, the East African Literature Bureau's weekly Tazama, and the publication Siku Hizi.

\title{
Social and Economic Studies in Leopoldville, Belgian Congo
}

THE Conference of the Inter-african Committee on Social Sciences held at Bukavu in August 1955 is expected to give a fresh stimulus to economic and social research in the Leopoldville area. Nevertheless some work had already been done. In July and August 1952, in connexion with the Ten-Year Development Plan, an extensive survey of the African labour force was 
carried out in Leopoldville, under the direction of M. Lagauche, consultant to a private engineering firm. Based on a detailed classification of jobs prepared for the purpose, the survey produced a very complete account of the rates of salaries and wages paid throughout the area. A report of the survey appears in the Bulletin Mensuel des Statistiques Generales du Congo Belge et du Ruanda-Urundi, August 1953, pp. 261-83. In December 1952-January I953 the Service de la Population Noire organized a survey of African trading in Leopoldville which was planned and carried out by M. P. M. Colin, Administrateur Territorial adjoint. The data collected included details of the number of traders, their ages, ethnic origins and the African labour employed by them. The results were analysed in a report prepared by the Service de la Population Noire entitled: Activites indépendantes à la cité indigène de Léopoldville. Étude faite en collaboration avec le Plan Décennal (Leopoldville, I955, pp. 96).

A population survey, using sampling methods which had already been tried out by I.R.S.A.C. in Ruanda-Urundi, has recently been completed in Leopoldville as part of a scheme which will cover the whole Congo territory. The work is being carried out jointly by the Service des Affaires Indigènes et de la Main-d'œuvre and the Government Statistical Department, under the direction of M. Romaniuk, and includes data on age, origin, family status, education and occupations of the native population. Partial results are being published in the Bulletin Mensuel des Statistiques Générales du Congo Belge et du Ruanda-Urundi. A recent article in Zaire comments on the population figures already published (Fr. Lamal, 'Considérations critiques sur des récents travaux de démographie congolaise', Zaïre, ix. 6, juin 1955). Further researches of this kind are being developed in connexion with the TenYear Plan, and the Department of Administration and Social Sciences of the University of Lovanium may be expected to enter the field also.

In view of the growing importance of Leopoldville with regard to the economic and social conditions of the African worker, research in this area should yield important results.

ANdré Van CaUwenbergh

\section{Enquête sur le Commerce indigène, Elisabethville}

LE Centre d'Étude des Problèmes Sociaux Indigènes (CEPSI) propose d'entreprendre une enquête sur le commerce indigène dans le centre extra-coutumier d'Élisabethville. C'est au moment actuel de l'évolution du commerçant noir qu'il convient d'étudier ses attitudes mentales et son comportement social, afin de déterminer l'orientation que prendra l'activité commerciale, d'adopter les mesures propres à favoriser l'épanouissement de cette activité et aussi de parer au danger que peut présenter la méconnaissance des lois économiques. L'hétérogénéité de la population bantoue qui peuple le C.E.C. permet l'examen des comportements des différents groupes ethniques en présence, et de constater si certaines règles communes s'établissent dans la pratique commerciale ou si, au contraire, les usages varient d'un groupe à l'autre. La présence d'un commerce pour indigènes tenu par des Européens et concentré à proximité du C.E.C. a favorisé les contacts entre Européens et Bantous. Ces derniers se sont très vraisemblablement inspirés de leurs méthodes. L'enquête démontrera dans quelle mesure ses méthodes ont été adoptées et comment elles ont été assimilées.

Un questionnaire a été dressé qui servira à cette étude. Établi primitivement en français, il a été traduit en kiswahili et discuté avec un groupe de notables noirs. Tous les commerçants et artisans libres du C.E.C. seront visités, le nombre de ceux-ci étant insuffisant pour permettre un traitement par des sondages. Le questionnaire concerne l'identité de chaque informateur (âge, groupe ethnique, lieu de naissance, origine des parents, état civil, teligion, régime parentelaire coutumier); études (scolarisation etc.); profession à Élisabethville; logement; propriétés; activité commerciale (lieu d'activité, genre d'activité, méthodes de vente, méthodes d'achat, revenus et chiffre d'affaires etc.). (Voir le Bulletin Trimestriel du CEPSI, juin I955.) 